\title{
Fermentation of melon seeds for "Ogiri egusi" as affected by fermentation variables using Bacillus subtilis
}

\author{
Chika Crescence Ogueke ${ }^{\star}$, Ada Innocentia Okoli, Clifford Ifeanyi Owuamanam and Ihuoma Ahaotu
}

Department of Food Science and Technology, Federal University of Technology Owerri, P.M.B. 1526 Owerri, Nigeria. Email: chikaogueke@yahoo.com

Received 5 October 2012; Received in revised form 2 November 2012; Accepted 7 November 2012

\begin{abstract}
Aims: Manipulation of fermentation variables during 'ogiri egusi' production using Bacillus subtilis was studied with the view to improving the fermentation process and quality of product. The variables studied were relative humidity $(\mathrm{RH})$, temperature and pore size of wrapping material.

Methodology and results: Effect of variables on amino nitrogen, $\mathrm{pH}$ and peroxide value was determined on $24 \mathrm{~h}$ basis for $96 \mathrm{~h}$. Attempt on optimization of process using response surface method was made. Amino nitrogen increased with fermentation time, the highest value $(6.25 \mathrm{mg} \mathrm{N} / \mathrm{g})$ being obtained from sample fermented at $75 \% \mathrm{RH}$, temperature 35 ${ }^{\circ} \mathrm{C}$ and $90 \mu \mathrm{m}$ pore size of wrapping material. Fermentation attained its peak at $48 \mathrm{~h}$ fermentation time. $\mathrm{pH}$ increased into the alkaline range within the period, the highest value (7.81) being from sample that gave the highest amount of amino nitrogen. Peroxide values obtained in all samples were far below the recommended value of $30 \mathrm{Meg} / \mathrm{kg}$. However, the highest value $(4.16 \mathrm{Keq} / \mathrm{kg})$ was obtained in sample fermented at $85 \% \mathrm{RH}$, temperature $30{ }^{\circ} \mathrm{C}$ and $70 \mu \mathrm{m}$ pore size of wrapper. Statistical analysis and response surface plots associated with analysis showed that the quadratic effect of variables was significant $(p=0.05)$. Effects of relative humidity and pore size of wrapping material were also significant and accounted for $99.56 \%$ of the amino nitrogen variation.

Conclusion, significance and impact study: Manipulation of the fermentation variables significantly improved the process. Thus use of response surface method optimized the fermentation process especially the effects of relative humidity and pore size of wrapping materials. The suggested combination of variables for optimum fermentation is $75 \%$ $\mathrm{RH}$, temperature $35^{\circ} \mathrm{C}$ and $70 \mu \mathrm{m}$ pore size of wrapper. This ultimately will improve product quality and reduce fermentation time.
\end{abstract}

Keywords: toxicity, Ogiri egusi, fermentation variables, response surface, Bacillus subtilis, amino nitrogen

\section{INTRODUCTION}

Melon seeds (Citrullus vulgaris) are presently fermented using traditional processes of uncontrolled solid state fermentation in Nigeria (Achi, 2005), where the product (ogiri egusi) is used as a condiment for flavouring soups and stews. The soup condiment is known to have high protein content, thus serving a dual purpose of flavouring as well as source of protein supplement (Abaelu et al., 1990).

Fermentation of ogiri egusi usually takes three to five days at the prevailing ambient temperature (Barber and Achinewhu, 1992; Omafvube et al., 2004) and relative humidity. Various workers have identified different microorganisms in fermented melon seeds (Barimalaa et al., 1989; Barber and Achinewhu, 1992; Sanni et al., 2000), however, Bacillus subtilis have been identified as the main bacterium involved in the fermentation (Barimalaa et al., 1989).

Ogiri egusi fermentation is still carried out using the traditional method. This involves boiling melon seeds, cooling, wrapping in leaves and fermenting at the prevailing temperature and relative humidity. The number and layer of leaves used in wrapping the seeds before fermentation vary depending on the individual carrying out the fermentation. Thus the rate of oxygen transfer to the fermenting microorganisms will vary from one batch of fermentation to another. Also the prevailing relative humidity and temperature vary from day to day and within regions and seasons. These variables usually account for the variations in product quality. This chance fermentation as practiced traditionally makes the fermentation difficult to control and results in the contamination of products with pathogens or other microorganisms capable of producing toxins and those that cause off flavours (Ogueke and Nwagwu, 2007). Attempts have been made by some workers (Abaelu et al., 1990; Ogueke and Nwagwu, 2007) to produce ogiri egusi using pure cultures of the bacteria isolated from previous ogiri egusi and fermented oil beans, thus introducing the use of starter cultures.

There is need to optimize the fermentation process with the view to industrializing the production. However, before this can be achieved, there is need to study all the

\section{*Corresponding author}


fermentation variables and how they interplay with each other, and how they affect the entire fermentation process and final product quality. This research work therefore aims at producing ogiri egusi from melon seeds under controlled conditions of temperature, relative humidity and pore size of wrapping material. The response surface methodology was used to study the optimization process.

\section{MATERIALS AND METHODS}

\section{Source of raw material}

About $15 \mathrm{~kg}$ of melon seeds (C. vulgaris) were purchased from Ihiagwa market in Owerri, Imo State, Nigeria in March, 2012. Seeds obtained were dehulled and sorted to remove bad seeds, hulls and extraneous materials. The seeds were stored at $4{ }^{\circ} \mathrm{C}$ until used for the study.

\section{Bacillus subtilis used for the study}

Bacteria were isolated from various samples from three states of the consuming region of South Eastern Nigeria. Microbiological analyses were conducted immediately by suspending $10 \mathrm{~g}$ of sample in $90 \mathrm{~mL}$ sterile maximum recovery diluents (MRD Oxoid CM0733) and homogenized using a Stomacher (A. J. Seward, BA6021) for 1 to $2 \mathrm{~min}$ at normal speed. Ten-fold dilutions were then prepared and $0.1 \mathrm{~mL}$ of suitable dilution was spread onto nutrient agar (NA, Oxoid CM0003). Plates were incubated aerobically at $37^{\circ} \mathrm{C}$ for $24-48 \mathrm{~h}$. Representative dominant colonies were picked and purified by streaking on same NA. Stock cultures were kept in nutrient broth containing $20 \%$ glycerol and stored at $-20{ }^{\circ} \mathrm{C}$. The identification of the isolates was done using the methods described by Ouoba et al. (2008).

Before use the identified $B$. subtilis were streaked on tryptone soy agar (BIOTEC) and incubated at $35^{\circ} \mathrm{C}$ for 18 $\mathrm{h}$. The cultures were then washed by suspending the cells in $10 \mathrm{~mL}$ of $0.1 \mathrm{M}$ potassium phosphate buffer $(\mathrm{pH} 7.0)$. This was followed by centrifugation at $14,000 \times g$ for 5 min. using an MSE centrifuge (Minor, UK) (Njoku et al., 1990).

\section{Preparation and standardization of inocula}

Cultures from $18 \mathrm{~h}$ tryptone soy agar plates (BIOTECH) were examined for purity by microscopic examination of slides prepared from randomly selected colonies. A loopful of the $18 \mathrm{~h}$ old culture was inoculated in a flask containing $50 \mathrm{~mL}$ of tryptone soy broth (Oxoid) and was incubated aerobically for $48 \mathrm{~h}$ at $35^{\circ} \mathrm{C}$. Cells from the broth culture were harvested and washed three times with $0.1 \mathrm{M}$ potassium phosphate buffer by centrifugation at $14,000 \mathrm{xg}$ for $5 \mathrm{~min}$. The cells were then aseptically resuspended in $20 \mathrm{~mL}$ sterile $0.1 \mathrm{M}$ potassium phosphate buffer ( $\mathrm{pH}$ 7.0). The cell suspension was then standardized using a spectrophometer (Model S2100UV, UNICO, New Jersey, USA) at $550 \mathrm{~nm}$ wavelength such that $1.0 \mathrm{~mL}$ of the suspension contained about $2.0 \times 10^{10}$ cells.

\section{Fermentation of melon seeds using standardized broth cultures of $B$. subtilis}

Seven hundred grams of dehulled melon seeds were properly sorted and cleaned, and extraneous materials removed. The seeds were boiled for 2-3 $\mathrm{h}$ until the endosperm softened, then drained and cooled to about 30 ${ }^{\circ} \mathrm{C}$, placed into a sterilized container and inoculated with $2.0 \mathrm{~mL}$ of the standardized broth cultures and mixed. Approximately $350 \mathrm{~g}$ were wrapped in polyethylene materials of different pore sizes $(50 \mu \mathrm{m}, 70 \mu \mathrm{m}$ and 90 $\mu \mathrm{m})$. The $50 \mu \mathrm{m}$ and $70 \mu \mathrm{m}$ materials were made of low density polyethylene material while $90 \mu \mathrm{m}$ material was made of high density polyethylene material. The pore sizes were previously determined by Isu and Njoku (1998). The wrapped melon seeds were then put in an incubator set at the appropriate temperatures (see experimental design) and allowed to ferment for four days. The same process was repeated for all the variables as shown in the experimental design.

\section{Experimental design}

A Box Behnken rotable response (Lawson and Madrigal, 1994) for $k=3$ was employed to study the linear, interactive, quadratic and cubic effects of the independent variables on the fermentation process. The variables were of three levels (Table 1). Samples/Runs 1-12 were performed once while sample/run 13 was performed three times to give a total of 15 experimental samples/runs.

\section{Generation of relative humidity $(\mathrm{RH})$}

The various relative humidity were generated as follows:

(i) $65 \% \mathrm{RH}$ was generated by dissolving $50 \mathrm{~g}$ of anhydrous $\mathrm{NaNO}_{3}$ in $33.3 \mathrm{~mL}$ of hot water.

(ii) $75 \% \mathrm{RH}$ was generated by dissolving $20 \mathrm{~g}$ of $\mathrm{NaCl}$ in $50 \mathrm{~mL}$ of hot water.

(iii) $85 \% \mathrm{RH}$ was generated by dissolving $25 \mathrm{~g}$ of $\mathrm{KCl}$ in $50 \mathrm{~mL}$ of hot water.

The salt solutions were put in the incubator to create the required relative humidity in the environment of fermentation. The fermentations were monitored on $24 \mathrm{~h}$ basis for the amino nitrogen content, $\mathrm{pH}$ and peroxide value.

\section{Determination of $\mathrm{pH}$}

The $\mathrm{pH}$ of each fermentation process was measured as follows. Five grams of fermenting seeds was taken from the bulk and mashed in $45 \mathrm{~mL}$ of sterile deionized water (Njoku et al., 1990). The $\mathrm{pH}$ was measured using a standardized $(\mathrm{pH}$ 4.0-9.0) digital $\mathrm{pH}$ meter (Jenway $\mathrm{pH} / \mathrm{MV} / \mathrm{TEMPERATURE}$ METER, Model 3510, Essex, UK) at ambient temperature $\left(30-32{ }^{\circ} \mathrm{C}\right)$.

\section{Amino nitrogen determination}

The formol titration method (Pham and Del-Rosario, 1983) was used for the determination of amino nitrogen in 
the samples. Three grams of fermenting seeds was taken and mashed. Two grams of the mashed seeds was placed in a conical flask, and then $0.5 \mathrm{~mL}$ of phenolphthalein $(0.5 \%)$ and $0.4 \mathrm{~mL}$ of neutral saturated potassium oxalate were added. The mixture was kept to stand for few minutes and this was neutralized with $0.1 \mathrm{M}$ $\mathrm{NaOH}$ to a standard pink color. Two milliliters of $40 \%$ formaldehyde solution was added and allowed to stand

Table 1: The independent variables, their levels and Combination of the independent variables.

\begin{tabular}{|c|c|c|c|}
\hline \multirow[t]{2}{*}{ Independent variables } & \multicolumn{3}{|c|}{ Variable levels } \\
\hline & -1 & 0 & +1 \\
\hline Relative humidity $\%\left(\mathrm{X}_{1}\right)$ & 65 & 75 & 85 \\
\hline Temperature ${ }^{\circ} \mathrm{C}\left(\mathrm{X}_{2}\right)$ & 30 & 35 & 40 \\
\hline Pore size $\mu \mathrm{m}\left(\mathrm{X}_{3}\right)$ & 50 & 70 & 90 \\
\hline Sample/Run & $X_{1}$ & $\mathrm{X}_{2}$ & $X_{3}$ \\
\hline 1 & -1 & -1 & 0 \\
\hline 2 & +1 & -1 & 0 \\
\hline 3 & -1 & +1 & 0 \\
\hline 4 & +1 & +1 & 0 \\
\hline 5 & -1 & 0 & -1 \\
\hline 6 & +1 & 0 & -1 \\
\hline 7 & -1 & 0 & +1 \\
\hline 8 & +1 & 0 & +1 \\
\hline 9 & -1 & -1 & -1 \\
\hline 10 & 0 & +1 & -1 \\
\hline 11 & 0 & -1 & +1 \\
\hline 12 & +1 & +1 & +1 \\
\hline 13 & 0 & 0 & $0 \times 3$ \\
\hline
\end{tabular}

for few minutes (until mixture was colorless). This was then titrated with $0.1 \mathrm{M} \mathrm{NaOH}$ to pink color. The titer value obtained was designated ' $\mathrm{V}_{1}$ '. A blank was run by titrating a mixture of $2 \mathrm{~mL}$ of formaldehyde solution and $10 \mathrm{~mL}$ distilled water with $0.1 \mathrm{M} \mathrm{NaOH}$ to obtain ' $\mathrm{V}_{2}$ '. The amino nitrogen was calculated using the equation: \% Amino Nitrogen $=1.7\left(\mathrm{~V}_{1}-\mathrm{V}_{2}\right)$.

\section{Determination of peroxide value}

Fifteen grams of fermenting seeds was mashed and $5 \mathrm{~g}$ of each of the mashed seeds was placed into a $250 \mathrm{~mL}$ glass - stopper Erlenmeyer flask, and $30 \mathrm{~mL}$ of solvent mixture ( 3 parts by volume of glacial acetic acid +2 parts by volume of chloroform) was added. The flask was swirled to dissolve the mashed seeds in the solution. Five hundred microliters of saturated potassium iodide solution was added and the solution was allowed to stand (with occasional shaking) for $1 \mathrm{~min}$, then $30 \mathrm{~mL}$ of distilled water was added. The mixture was titrated by gradually adding $0.1 \mathrm{~N}$ sodium thiosulphate and constantly shaking vigorously. The titration continued until the yellow color had almost disappeared. Five hundred microliters of starch indicator solution was added. The titration was continued, shaking the flask vigorously at near end point until the iodine from the chloroform layer was liberated. The sodium thiosulphate was then added drop wise until the blue color had just disappeared. The tubes were placed in boiling water to boil for about $30 \mathrm{sec}$. A blank 
was also prepared at the same time. The peroxide value per $1000 \mathrm{~g}$ of sample was calculated using the equation described below:

Peroxide value $=\frac{(\mathrm{S}-\mathrm{B}) \times(\mathrm{N}) \times(1000)}{\mathrm{W}}$

$B=$ Titration of blank

$\mathrm{S}=$ Titration of sample

$\mathrm{W}=$ Weight of sample

$\mathrm{N}=$ Normality of sodium thiosulfate solution

All analyses were carried out in triplicate.

\section{Statistical analysis}

The data obtained from the study were analyzed statistically using Analysis of Variance (ANOVA). The means were separated using Fisher's Least Significant Difference (LSD). The response surface plots and their analyses were done using Design - Expert software version 8. 0.7. 1 .

\section{RESULTS AND DISCUSSIONS}

The amino nitrogen values obtained during the fermentation of melon seeds increased as fermentation time increased (result not included). At $96 \mathrm{~h}$ the highest value of amino nitrogen was obtained in the sample fermented at $75 \%$ relative humidity $(\mathrm{RH})$, temperature 35 ${ }^{\circ} \mathrm{C}$ and wrapped with $90 \mu \mathrm{m}$ pore size material (sample $11)$, with a value of $6.25 \mathrm{mg} \mathrm{N} / \mathrm{g}$. The least value $(5.06 \mathrm{mg}$ $\mathrm{N} / \mathrm{g}$ ) was obtained from the sample fermented at $65 \% \mathrm{RH}$, temperature $30{ }^{\circ} \mathrm{C}$ and wrapped in $50 \mu \mathrm{m}$ pore size material (sample 9).

Table 2 shows the daily amino nitrogen production during the fermentation period. Close observation of the results showed that in majority of the fermentations the largest amounts were produced at $48 \mathrm{~h}$, thus indicating that the fermentations got to their peaks at $48 \mathrm{~h}$ except the sample fermented at $85 \% \mathrm{RH}$, temperature $40{ }^{\circ} \mathrm{C}$ and wrapped with $70 \mu \mathrm{m}$ pore size which got to its peak at 72 h. The largest amount of amino nitrogen produced at 48 $\mathrm{h}$ was $1.63 \mathrm{mg} \mathrm{N} / \mathrm{g}$, and was obtained

Table 2: Daily amino nitrogen levels during fermentation ( $\mathrm{mg} \mathrm{N} / \mathrm{g})$.

\begin{tabular}{cccccc}
\hline Sample/Run & \multicolumn{5}{c}{ Period of fermentation (h) } \\
\cline { 2 - 6 } & 0 & 24 & 48 & 72 & $0.39^{\mathrm{a}, \mathrm{d}}$ \\
\hline 1 & 0 & $0.36^{\mathrm{a}}$ & $0.93^{\mathrm{a}, \mathrm{e}}$ & $0.03^{\mathrm{a}}$ \\
2 & 0 & $0.53^{\mathrm{b}}$ & $1.50^{\mathrm{b}, \mathrm{g}}$ & $0.52^{\mathrm{a}}$ & $0.38^{\mathrm{b}}$ \\
3 & 0 & $0.53^{\mathrm{b}}$ & $1.31^{\mathrm{c}}$ & $0.07^{\mathrm{b}}$ & $0.25^{\mathrm{c}}$ \\
4 & 0 & $0.41^{\mathrm{a}, \mathrm{b}}$ & $0.39^{\mathrm{d}}$ & $1.07^{\mathrm{c}}$ & $0.17^{\mathrm{d}}$ \\
5 & 0 & $0.48^{\mathrm{b}}$ & $1.06^{\mathrm{e}, \mathrm{f}}$ & $0.30^{\mathrm{d}}$ & $0.29^{\mathrm{c}}$ \\
6 & 0 & $0.17^{\mathrm{c}}$ & $1.11^{\dagger}$ & $0.22^{\mathrm{d}, \mathrm{e}}$ & $0.14^{\mathrm{d}, \mathrm{t}}$ \\
7 & 0 & $0.27^{\mathrm{c}, \mathrm{d}}$ & $1.31^{\mathrm{c}}$ & $0.16^{\mathrm{e}}$ & $0.31^{\mathrm{e}}$ \\
8 & 0 & $0.30^{\mathrm{d}}$ & $1.29^{\mathrm{c}}$ & $0.14^{\mathrm{e}}$ & $0.19^{\mathrm{d}}$ \\
9 & 0 & $0.16^{\mathrm{c}}$ & $1.13^{\mathrm{t}}$ & $0.07^{\mathrm{b}}$ & $0.05^{\mathrm{a}, \mathrm{g}}$ \\
10 & 0 & $0.41^{\mathrm{a}, \mathrm{b}}$ & $1.28^{\mathrm{c}}$ & $0.18^{\mathrm{e}}$ & $0.14^{\mathrm{d}, \mathrm{t}}$ \\
11 & $1.11^{\mathrm{e}}$ & $1.63^{\mathrm{g}}$ & $0.13^{\mathrm{e}}$ & $0.11^{\dagger}$ \\
12 & 0 & $0.73^{\dagger}$ & $1.62^{\mathrm{g}}$ & $0.11^{\mathrm{e}}$ & $0.09^{\mathrm{g}}$ \\
$13^{*}$ & 0 & $0.99^{\mathrm{e}}$ & $1.57^{\mathrm{g}}$ & $0.16^{\mathrm{e}}$ & $0.15^{\mathrm{d}}$ \\
LSD & 0 & 0.133 & 0.153 & 0.125 & 0.048
\end{tabular}

${ }^{*}$ Average of three readings

$\mathrm{a}, \mathrm{b}, \mathrm{c}$...Values on the same column with the same superscript are not significantly different $(p=0.05)$. 
from the sample fermented at $75 \% \mathrm{RH}$, temperature 35 ${ }^{\circ} \mathrm{C}$ and wrapped with $90 \mu \mathrm{m}$ pore size wrapping material. This was closely followed by the value obtained from the sample fermented at $85 \% \mathrm{RH}$, temperature $40{ }^{\circ} \mathrm{C}$ and wrapped with $90 \mu \mathrm{m}$ pore size material $(1.62 \mathrm{mg} \mathrm{N} / \mathrm{g})$. It could be that the combinations of the variables favoured the activities of the fermenting bacterium, especially the increased pore size which allowed more $\mathrm{O}_{2}$ penetration. The fermenting bacterium $B$. subtilis is a highly aerobic organism; therefore more $\mathrm{O}_{2}$ will increase the rate of growth and general activities of the bacterium resulting in an increased proteinase activity and more amino acid and thus increased amino nitrogen production. Statistical analysis of the values showed that their values at $48 \mathrm{~h}$ significantly differed $(p<0.05)$ from the values obtained from the other samples except the $13^{\text {th }}$ and $2^{\text {nd }}$ samples which had values of $1.57 \mathrm{mg} \mathrm{N} / \mathrm{g}$ and $1.50 \mathrm{mg} \mathrm{N} / \mathrm{g}$ respectively.
The apparent increase in the fermentation rate and the higher levels of amino nitrogen obtained in the study could probably be due to increased cell density per unit of fermenting mash as has been suggested by Isu and Ofuya (2000), and enhanced cell wall permeability and metabolism. In this study the fermenting mash was inoculated with broth cultures containing about $2.0 \times 10^{10}$ $\mathrm{cfu} / \mathrm{mL}$ of cells. The traditional fermentation method usually takes three to five days to complete (Barber and Achinewhu, 1992; Omafuvbe et al., 2004).

Table 3 shows the analysis of variance for the response surface quadratic model for amino nitrogen content of ogiri egusi. $p$ - values less than 0.0500 are significant thus the model response was significant $(p<$ 0.05 ). The effects of relative humidity and pore size were also significant. These variables accounted for $99.56 \%$ of

Table 3: ANOVA table for response surface quadratic model (Amino nitrogen).

\begin{tabular}{|c|c|c|c|c|c|}
\hline Source & Sum of & Df & Mean square & $F-$ value & $\begin{array}{l}p-\text { value } \\
\text { Prob> F }\end{array}$ \\
\hline Model & 0.14 & 9 & 0.015 & 125.74 & $<0.0001$ \\
\hline A-Relative & 0.036 & 1 & 0.036 & 301.07 & $<0.0001$ \\
\hline \multicolumn{6}{|l|}{ Humidity } \\
\hline B-Temperature & 4.948E-005 & 1 & 4.948E-005 & 0.41 & 0.5504 \\
\hline C-Pore size & 0.012 & 1 & 0.012 & 96.72 & 0.0002 \\
\hline$A B$ & 8.473E-005 & 1 & 8.473E-005 & 0.70 & 0.4405 \\
\hline$A C$ & 8.344E-004 & 1 & 8.344E-004 & 6.91 & 0.0466 \\
\hline $\mathrm{BC}$ & 4.243E-003 & 1 & 4.243E-003 & 35.12 & 0.0020 \\
\hline$A^{2}$ & 0.025 & 1 & 0.025 & 208.53 & $<0.0001$ \\
\hline$B^{2}$ & $3.218 E-003$ & 1 & $3.218 E-003$ & 26.64 & 0.0036 \\
\hline $\mathrm{C}^{2}$ & $9.703 E-003$ & 1 & $9.703 E-003$ & 80.32 & 0.0003 \\
\hline Residual & $6.040 \mathrm{E}-004$ & 5 & $1.208 \mathrm{E}-004$ & & \\
\hline Lack of fit & 5.934E-004 & 3 & 1.978E-004 & 37.20 & 0.0263 \\
\hline Pure error & 1.063E-005 & 2 & 5.316E-006 & & \\
\hline Cor Total & 0.14 & 14 & & & \\
\hline
\end{tabular}

the amino nitrogen variation in ogiri egusi (Table 4). Response surface plots associated with the analysis are shown in figures 1 to 3 . The effects of relative humidity and pore size of wrapper (AC), and temperature and pore size of wrapper $(B C)$ on amino nitrogen were significant $(p<0.05)$. The $p-$ values were less than 0.0500 . The suggested combination of variables for optimum fermentation of ogiri egusi is $75 \%$ relative humidity, temperature of $35{ }^{\circ} \mathrm{C}$ and $70 \mu \mathrm{m}$ pore size of wrapping material. 
Mal. J. Microbiol. Vol 9(4) 2013, pp. 279-288

Table 4: Model Summary Statistics for amino nitrogen.

\begin{tabular}{|c|c|c|c|c|c|}
\hline Source & Dev. & R-Squared & $\begin{array}{l}\text { Adjusted R- } \\
\text { Squared }\end{array}$ & $\begin{array}{l}\text { Predicted R- } \\
\text { Squared }\end{array}$ & PRESS \\
\hline Linear & 0.075 & 0.5502 & 0.4276 & 0.3208 & 0.093 \\
\hline $2 \mathrm{FI}$ & 0.087 & 0.5591 & 0.2284 & -0.2611 & 0.17 \\
\hline Quadratic & 0.011 & 0.9956 & 0.9877 & 0.9076 & 0.013 \\
\hline Cubic & 2.306E-003 & 0.9999 & 0.9995 & & + \\
\hline
\end{tabular}

+ Case(s) with leverage of 1.0000: PRESS statistic not defined

"Model Summary Statistics": Focus on the model maximizing the "Adjusted R-Squared" and the "Predicted R-Squared".

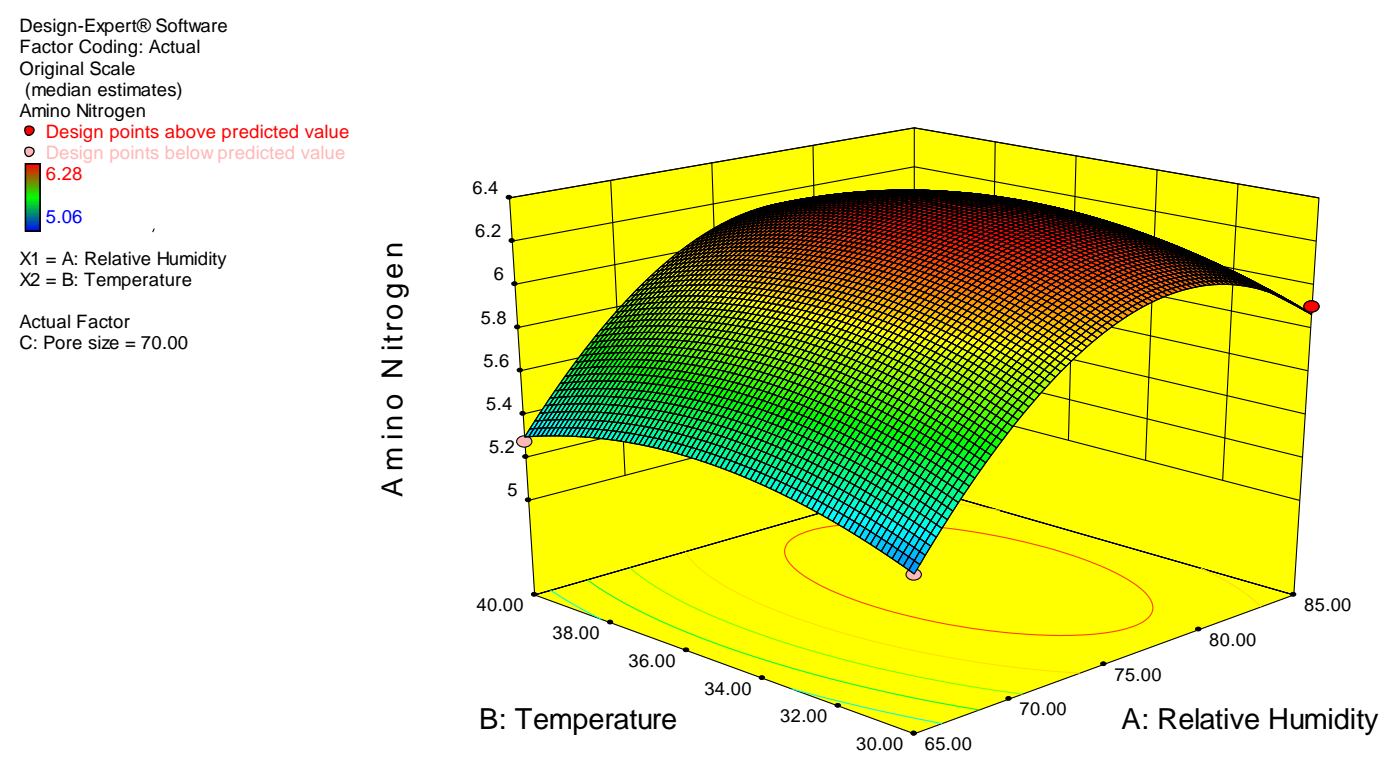

Figure 1: Effect of temperature and relative humidity on amino nitrogen content of ogiri egusi.
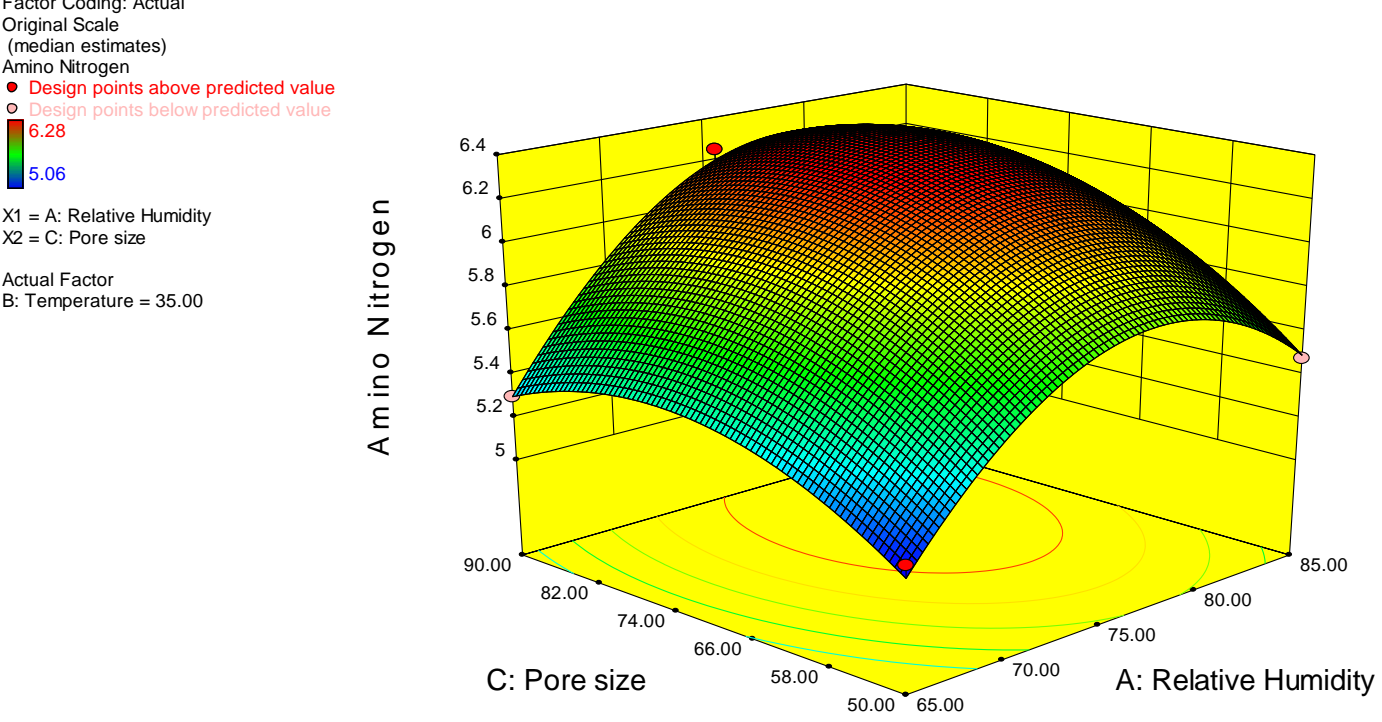

Figure 2: Effect of pore size and relative humidity on the amino nitrogen content of ogiri egusi. 


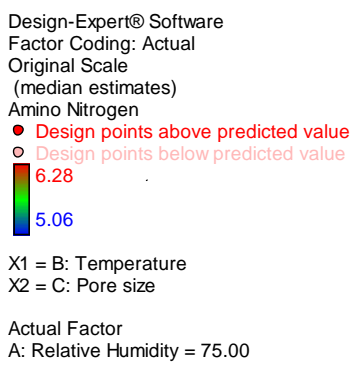

A: Relative Humidity $=75.00$

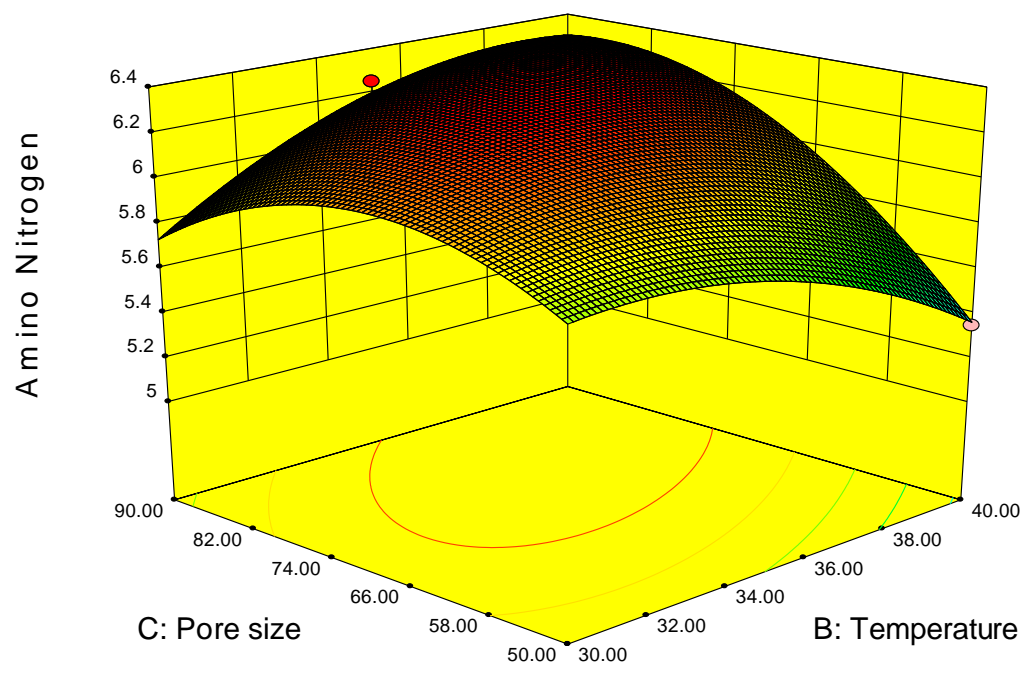

Figure 3: Effect of pore size and temperature on the amino nitrogen content of ogiri egusi.

The final Equation in Terms of Actual Factors is as follows:

Sqrt(Amino Nitrogen) $=-5.43023+$
$0.16989 \times$ Relative Humidity $+0.074371 \times$ Temperature 1.66684E-003 x Pore size - 9.13819E-005 x Relative Humidity $x$ Temperature $+7.16940 \mathrm{E}-005 \times$ Relative Humidity $x$ Pore size $+5.45288 E-004 \times$ Temperature $x$ Pore size - 1.10246E-003 x Relative Humidity2 1.50119E-003 x Temperature2 - 1.47656E-004 x Pore size2

While the Final Equation in Terms of Coded Factors is shown below:

Sqrt(Amino Nitrogen) $=+2.51+0.063 \times \mathrm{A}+$ 3.021E-003 $\times \mathrm{B}+0.042 \times \mathrm{C}-4.569 \mathrm{E}-003 \times \mathrm{A} \times \mathrm{B}+$ $0.014 \times A \times C+0.055 \times B \times C-0.11 \times A 2-0.038 \times B 2-$ $0.059 \times \mathrm{C} 2$

The $\mathrm{pH}$ values obtained during fermentation of melon seeds increased from start of fermentation till $96 \mathrm{~h}$ (Table 5). All the values at $96 \mathrm{~h}$ were in the alkaline range, thus it is an alkaline fermentation. Similar trends have been observed during the fermentation of some other protein rich plant materials (Ikenebomeh et al., 1986; Njoku and Okemadu, 1989) and also in agreement with the findings of Ogueke and Nwagwu (2007) who conducted a comparative study of the use of pure cultures of microorganisms isolated from previous ogiri egusi in the fermentation of melon seeds. The highest value obtained at $96 \mathrm{~h}$ was 7.81 observed in the sample fermented at $75 \% \mathrm{RH}$, temperature $35{ }^{\circ} \mathrm{C}$ and wrapped with $90 \mu \mathrm{m}$ pore size material (sample 11) while the least value (7.16) was observed in the sample fermented at $65 \% \mathrm{RH}$, temperature $30{ }^{\circ} \mathrm{C}$ and wrapped with $70 \mu \mathrm{m}$ pore size material (sample 1). The increase in $\mathrm{pH}$ within $24 \mathrm{~h}$ was not significant $(p>0.05)$ in all the samples while at $48 \mathrm{~h}$ the increase in some of the samples was significant $(p<0.05)$. Significant increases were observed at $72 \mathrm{~h}$ and $96 \mathrm{~h}$ in majority of the samples. Among the samples, significant differences $(p<0.05)$ were observed but there was no ordered pattern in the differences.

$\mathrm{pH}$ increase to the alkaline range is peculiar with fermentations of protein rich foods (Odunfa, 1982; 1985), and the increase has been attributed to increased proteinase and deaminase activities of the fermenting bacterium resulting in the liberation of ammonia through the utilization of amino acids, and possibly other basic end products of protein decomposition (Odunfa and Oyeyiola, 1985; Njoku and Okemadu, 1989; Sarker et al., 1993). These may be responsible for the pungent odour observed in the products, and also with well fermented traditionally produced ogiri egusi. However, high levels of ammonia nitrogen are undesirable in some foods because of their adverse effects on product flavour and aroma. Ammonia production is probably a common feature during fermentation of protein rich plant materials; ammonia is produced during Bacillus fermentation of soybean (Sarker et al., 1993), during fermentation of African Oilbean seeds for ugba (Njoku and Okemadu, 1989) and fermentation of African Locust bean seeds for Iru (Odunfa, 1981). Some workers (Yong and Wood, 1977) have suggested that in good quality soysauce ammonia nitrogen should constitute about $10-15 \%$ of total soluble nitrogen, thus Njoku and Okemadu (1989) has suggested that there should be monitoring of enzyme activity during fermentation for improved product quality. 
Table 5: $\mathrm{pH}$ values of the fermenting melon seeds.

\begin{tabular}{|c|c|c|c|c|c|c|}
\hline \multirow[t]{2}{*}{ Sample/Run } & \multicolumn{6}{|c|}{ Period of fermentation (h) } \\
\hline & 0 & 24 & 48 & 72 & 96 & LSD \\
\hline 1 & ${ }^{\mathrm{a}} 5.94^{1}$ & ${ }^{\mathrm{a}} 6.08^{1}$ & ${ }^{\mathrm{a}} 6.13^{1}$ & ${ }^{\mathrm{a}} 6.65^{2}$ & ${ }^{\mathrm{a}} 7.16^{3}$ & 0.40 \\
\hline 2 & ${ }^{\mathrm{b}, \mathrm{d}} 6.15^{1}$ & ${ }^{\mathrm{b}} 6.32^{1}$ & ${ }^{\mathrm{b}} 7.18^{2}$ & ${ }^{\mathrm{c}, \mathrm{t}} 7.23^{2}$ & b $7.31^{2}$ & 0.44 \\
\hline 3 & ${ }^{c} 5.82^{1}$ & ${ }^{c} 5.90^{1}$ & ${ }^{b} 7.15^{2}$ & ${ }^{\mathrm{b}} 6.82^{2}$ & b $7.31^{2}$ & 0.55 \\
\hline 4 & ${ }^{\mathrm{b}} 6.19^{1}$ & ${ }^{d} 6.25^{1}$ & ${ }^{a, c} 6.24^{1}$ & ${ }^{\mathrm{c}} 7.12^{2}$ & ${ }^{\mathrm{b}, \mathrm{d}} 7.37^{2}$ & 0.44 \\
\hline 5 & ${ }^{\mathrm{a}} 5.96^{1}$ & ${ }^{\mathrm{e}, \mathrm{t}} 6.12^{1}$ & ${ }^{a, c} 6.15^{1}$ & ${ }^{\mathrm{b}} 6.78^{2}$ & ${ }^{\mathrm{b}} 7.28^{3}$ & 0.44 \\
\hline 6 & ${ }^{\mathrm{b}} 6.18^{1}$ & ${ }^{d} 6.25^{1}$ & ${ }^{\circ} 6.35^{1}$ & ${ }^{c, t} 7.21^{2}$ & ${ }^{c} 7.80^{3}$ & 0.56 \\
\hline 7 & ${ }^{d} 6.12^{1}$ & ${ }^{\mathrm{d}, \mathrm{t}} 6.22^{1}$ & ${ }^{a, c} 6.29^{1}$ & ${ }^{c} 7.16^{2}$ & ${ }^{e} 7.56^{2}$ & 0.51 \\
\hline 8 & ${ }^{b, d} 6.14^{1}$ & ${ }^{\mathrm{e}, \mathrm{t}} 6.16^{1}$ & ${ }^{b} 7.13^{2}$ & ${ }^{d} 7.40^{2,3}$ & ${ }^{c} 7.75^{3}$ & 0.57 \\
\hline 9 & ${ }^{b, d} 6.14^{1}$ & ${ }^{d} 6.24^{1}$ & ${ }^{b} 7.08^{2}$ & ${ }^{d} 7.36^{2}$ & $\mathrm{~b}, \mathrm{~d} 7.39^{2}$ & 0.48 \\
\hline 10 & ${ }^{\mathrm{a}} 5.96^{1}$ & ${ }^{e, t} 6.16^{1}$ & ${ }^{a, c} 6.32^{1}$ & ${ }^{\mathrm{e}} 6.94^{2}$ & ${ }^{\mathrm{d}, \mathrm{e}} 7.46^{3}$ & 0.49 \\
\hline 11 & ${ }^{d} 6.11^{1}$ & ${ }^{\mathrm{d}, \mathrm{t}} 6.21^{1}$ & ${ }^{a, c} 6.27^{1}$ & ${ }^{\mathrm{c}, \mathrm{t}} 7.21^{2}$ & ${ }^{c} 7.81^{2}$ & 0.59 \\
\hline 12 & ${ }^{\mathrm{b}} 6.18^{1}$ & ${ }^{\mathrm{d}} 6.24^{1}$ & ${ }^{d} 6.91^{2}$ & ${ }^{t} 7.29^{2,3}$ & ${ }^{c} 7.79^{3}$ & 0.54 \\
\hline $13^{*}$ & ${ }^{\mathrm{e}} 6.05^{1}$ & ${ }^{\dagger} 6.17^{1}$ & ${ }^{a, c} 6.25^{1}$ & ${ }^{\mathrm{e}} 6.95^{2}$ & ${ }^{\mathrm{d}, \mathrm{e}} 7.45^{3}$ & 0.47 \\
\hline LSD & 0.05 & $0.05^{1}$ & 0.20 & 0.11 & 0.10 & \\
\hline
\end{tabular}

${ }^{*}$ Average of three readings

$a, b, c \ldots$. Values on the same column with the same superscript are not significantly different $(p=0.05)$.

$1,2,3 \ldots$. Values on the same row with the same superscript are not significantly different $(p=0.05)$.

However, ammonia nitrogen was not determined in this study.

Table 6 shows the peroxide value obtained from the samples of ogiri egusi fermented at different fermentation variables. Peroxide values of some of the samples increased with fermentation time except for samples 2, 3, 4 and 5 which increased upto $72 \mathrm{~h}$. The highest values were not near the threshold value of 30 milliequivalent of active $\mathrm{O}_{2}$ per kilogram (Meq/ $/ \mathrm{kg}$ ) of oil in oil rich foods (Gotoh and Wada, 2006). At $96 \mathrm{~h}$ the maximum value of $4.08 \mathrm{Meq} / \mathrm{kg}$ was obtained in sample 6 while the least value $(3.27 \mathrm{Meq} / \mathrm{kg})$ was obtained in sample 12 . The highest value in the entire fermentation (4.16 Meq/kg) was obtained in sample 2. Since the peroxide value is used as a measure of the extent to which rancidity can occur (Ihekoronye and Ngoddy, 1985) the lower values obtained in the entire fermentation showed that the chances of the product going rancid is very low and thus cannot introduce off flavour to soups and stews prepared with the condiment. Higher values above $30 \mathrm{Meq} / \mathrm{kg}$ may represent either the beginning of oxidation or advanced oxidation (Gotoh and Wada, 2006). The generally low values may be because the fermenting bacterium has very low lipolytic activity.

\section{CONCLUSION}

Ogiri egusi still remains an indigenous fermented soup condiment that constitutes an important social agro sustainable business that guarantees an additional income to families. They are also rich in protein thus serving a dual purpose of flavouring and source of protein supplement. Daily amino nitrogen production showed that the highest amounts of amino nitrogen were produced at $48 \mathrm{~h}$, thus reducing fermentation time from $96-120 \mathrm{~h}$ which is obtainable in natural fermentation to $48 \mathrm{~h}$. By manipulation of the fermentation variables products with increased amounts of amino nitrogen and lower levels of peroxide values were produced. These variables accounted for $99.56 \%$ of the amino nitrogen variation. This method could therefore be explored to improve production and guarantee product quality. This will also create wealth and financial benefits. Thus optimization of the process could be achieved through this means with 
Table 6: Peroxide values obtained during the fermentation at different fermentation variables (Meq/kg).

\begin{tabular}{|c|c|c|c|c|c|}
\hline \multirow[t]{2}{*}{ Sample/Run } & \multicolumn{5}{|c|}{ Period of fermentation (h) } \\
\hline & 0 & 24 & 48 & 72 & 96 \\
\hline 1 & $2.65^{\mathrm{b}}$ & $2.91^{\mathrm{e}}$ & $3.06^{\mathrm{e}}$ & $3.28^{\mathrm{d}, \mathrm{e}}$ & $3.75^{b}$ \\
\hline 2 & $2.80^{d}$ & $3.37^{a}$ & $3.64^{b}$ & $4.16^{\mathrm{a}}$ & $3.81^{b}$ \\
\hline 3 & $2.69^{b, c}$ & $2.76^{\dagger}$ & $3.94^{\mathrm{a}}$ & $4.09^{a}$ & $3.52^{\mathrm{c}, \mathrm{d}}$ \\
\hline 4 & $2.76^{\mathrm{c}, \mathrm{d}}$ & $3.24^{b}$ & $3.90^{\mathrm{a}}$ & $3.45^{\mathrm{b}, \mathrm{c}}$ & $3.50^{\mathrm{d}, \mathrm{e}}$ \\
\hline 5 & $2.85^{\mathrm{d}, \mathrm{f}}$ & $2.94^{\mathrm{e}}$ & $2.95^{\mathrm{t}, \mathrm{g}}$ & $3.57^{b}$ & $3.62^{c}$ \\
\hline 6 & $2.73^{c}$ & $3.20^{b, c}$ & $3.25^{c}$ & $3.61^{b}$ & $4.08^{\mathrm{a}}$ \\
\hline 7 & $2.90^{\dagger, g}$ & $2.94^{\mathrm{e}}$ & $3.09^{e, t}$ & $3.20^{\mathrm{e}}$ & $3.30^{t, e}$ \\
\hline 8 & $2.85^{\mathrm{d}, \mathrm{t}}$ & $3.15^{\mathrm{b}, \mathrm{c}, \mathrm{d}}$ & $3.22^{\mathrm{c}, \mathrm{d}, \mathrm{e}}$ & $3.38^{\mathrm{c}, \mathrm{d}}$ & $3.52^{\mathrm{c}, \mathrm{d}}$ \\
\hline 9 & $3.19^{e}$ & $3.12^{\mathrm{c}, \mathrm{d}}$ & $3.17^{\mathrm{c}, \mathrm{d}, \mathrm{e}}$ & $3.24^{\mathrm{d}, \mathrm{e}}$ & $3.36^{e}$ \\
\hline 10 & $2.95^{\mathrm{g}}$ & $2.97^{e}$ & $3.19^{c, d, e}$ & $3.30^{\mathrm{d}, \mathrm{e}}$ & $3.45^{\mathrm{d}, \mathrm{e}}$ \\
\hline 11 & $2.5^{\mathrm{n}}$ & $2.97^{e}$ & $3.06^{e, t}$ & $3.18^{e, t}$ & $3.41^{e}$ \\
\hline 12 & $3.04^{\mathrm{a}}$ & $3.10^{\mathrm{d}}$ & $3.12^{\mathrm{d}, \mathrm{e}}$ & $3.22^{\mathrm{d}, \mathrm{t}}$ & $3.27^{\dagger}$ \\
\hline $13^{*}$ & $2.64^{\mathrm{b}}$ & $2.74^{\dagger}$ & $2.81^{g}$ & $3.06^{\dagger}$ & $3.45^{\mathrm{d}, \mathrm{e}}$ \\
\hline LSD & 0.084 & 0.086 & 0.160 & 0.156 & 0.104 \\
\hline
\end{tabular}

the suggested combination of variables being temperature $35^{\circ} \mathrm{C}$, relative humidity $75 \%$ and $70 \mu \mathrm{m}$ pore size of wrapping material.

\section{REFERENCES}

Abaelu, A. M., Olukoya, D. K., Okochi, V. I. and Akinrimisi, E. O. (1990). Biochemical changes in fermented melon (egusi) seeds (Citrullus vulgaris). Journal of Industrial Microbiology 6, 211-214.

Achi, O. K. (2005). Traditional fermented protein condiments in Nigeria. African Journal of Biotechnology 4 (13), 1612-1621.

Barber, L. I. and Achinewhu, S. C. (1992). Microbiology of Ogiri production from melon seeds (Citrullus vulgaris). Nigerian Food Journal 10, 129-135.

Barimalaa, I. S., Achinewhu, S. C., Yibatima, I. and Amadi, E. N. (1989). Studies on the solid state fermentation of Bambara Groundnut (Vigna subterranean L.). Journal of Science of Food and Agriculture 66, 443-451.

Gotoh, N. and Wada, S. (2006). Importance of peroxide value in assessing food quality and food safety. Journal of the American Oil Chemists' Society 83(5), 473-474.
Ihekoronye, A. I. and Ngoddy, P. O. (1985). Integrated Food Science and Technology for the Tropics. Macmillian Publishers, London. pp. 123-127.

Ikenebomeh, M. J., Kiok, R. and Ingramm, J. M. (1986). Processing and fermentation of the African locust bean (Parkia filicoidea Welw) to produce dawadawa. Journal of Science of Food and Agriculture 37, 272282.

Isu, N. R. and Njoku, H. O. (1998). Studies on the influence of temperature, relative humidity and microenvironment on the natural fermentation of African oil bean seeds to Ugba. Plant Foods for Human Nutrition 52, 337-351.

Isu, N. R. and Ofuya, C. O. (2000). Improvement of the traditional processing and fermentation of African oil bean (Pentaclethra macrophylla Bentham) into a food snack - 'ugba'. International Journal of Food Microbiology 59, 235-239.

Lawson, J. S. and Madrigal, J. L. (1994). Robust design through optimization techniques. Quality Engineering 6, 593-608.

Njoku, H. O., Ogbulie, J. N. and Nnubia, C. (1990). African oil bean (Pentaclethra macorphylla Bentham) for ugba production. Journal of Food Science 49, 1326. 
Njoku, H. O. and Okemadu, C. P. (1989). Biochemical changes during the natural fermentation of the African Oilbean (Pentaclethra macrophylla) for the production of Ugba. Journal of Science of Food and Agriculture. 49, 457-465.

Odunfa, S. A. (1981). Microorganisms associated with fermentation of African locust bean during iru preparation. Journal of Plant Foods 3, 245-250.

Odunfa, S. A. (1982). Biochemical changes during melon fermentation for ogiri production. Journal of Plant Foods 4, 111-116.

Odunfa, S. A. (1985). Biochemical changes in fermenting African locust bean (Parkia biglobosa) during 'Iru' fermentation. Journal of Food Technology 20, 295303.

Odunfa, S. A. and Oyeyiola, G. F. (1985) Microbiological study of the fermentation of 'Ugba' - a Nigerian indigenous fermented food flavor. Journal of Plant Foods 6, 155-163.

Ogueke, C. C. and Nwagwu, A. (2007). Comparative study of melon seeds (Citrullus vulgaris) fermented with mixed cultures and pure cultures of bacteria isolates from Ogiri Egusi. Life Science Journal 4 (4), 41-46.
Omafuvbe, B. O., Falade, O. S., Osuntogun, B. A. and Adewusi, S. R. (2004). Chemical and biochemical changes in African locust bean (Parkia biglobosa) and melon (Citrullus vulgaris) seeds during fermentation of condiments. Pakistan Journal of Nutrition 3(3), 140-145.

Ouoba, L. I. I., Parkouda, C., Diawara, B., Scotti, C. and Varnam, A. H. (2008). Identification of Bacillus spp. from Bikalga, fermented seeds of Hibiscus sabdariffa: Phenotypic and genotypic characterization. Journal of Applied Microbiology 104, 122-131.

Pham, C. B. and Del-Rosario, R. R. (1983). The preparation of protein hydrolysate from deffated coconut and soya-bean meals. Effect of process variable on the amino-nitrogen released and flavour development. Journal of Food Technology 18, 21-34.

Sanni, A. I., Ayenor, G. S., Sakyi-Dawson, E. and SefaDedeh, S. (2000). Aerobic spore forming bacteria and chemical composition of some Nigerian fermented soup condiments. Plant Foods for Human Nutrition 55 (2), 111-118.

Sarker, P. K., Cook, P. E. and Owens, J. D. (1993). Bacillus fermentation of soybean. World Journal of Microbiology and Biotechnology. 9, 295-299.

Yong, F. M. and Wood, B. J. B. (1977). Biochemical changes in experimental soy sauce koji. Journal of Food Technology 12, 163-175. 